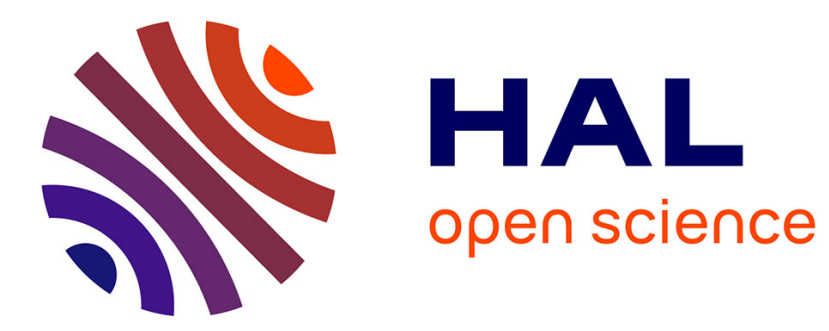

\title{
Consumers' brand heritage experience: between acceptance and resistance
}

Rémi Mencarelli, Damien Chaney, Mathilde Pulh

\section{To cite this version:}

Rémi Mencarelli, Damien Chaney, Mathilde Pulh. Consumers' brand heritage experience: between acceptance and resistance. Journal of Marketing Management, 2020, 36 (1-2), pp.30-50. 10.1080/0267257X.2019.1692057 . hal-02380341

\section{HAL Id: hal-02380341 https://hal.science/hal-02380341}

Submitted on 26 Nov 2019

HAL is a multi-disciplinary open access archive for the deposit and dissemination of scientific research documents, whether they are published or not. The documents may come from teaching and research institutions in France or abroad, or from public or private research centers.
L'archive ouverte pluridisciplinaire $\mathbf{H A L}$, est destinée au dépôt et à la diffusion de documents scientifiques de niveau recherche, publiés ou non, émanant des établissements d'enseignement et de recherche français ou étrangers, des laboratoires publics ou privés. 


\section{Consumers' brand heritage experience: between acceptance and resistance}

Rémi Mencarelli ${ }^{\mathrm{a}}$, Damien Chaney ${ }^{\mathrm{b}^{*}}$ and Mathilde Pulh ${ }^{\mathrm{c}}$

${ }^{a}$ University of Savoie Mont-Blanc, Annecy-Le-Vieux, France ; ${ }^{b}$ South Champagne Business

School, Troyes, France ; ${ }^{c}$ University of Burgundy, Dijon, France

Damien Chaney, Associate Professor of Marketing, South Champagne Business School,

Laboratoire Regards EA 6292, , 217 avenue Pierre Brossolette, 10002 TROYES cedex, France,

Tel: +33 3257122 30, email: damien.chaney@get-mail.fr 


\section{Consumers' brand heritage experience: between acceptance and resistance}

The literature dedicated to heritage experience and brand heritage defends the idea that it is a source of significant value creation for consumers and brands. By contrast, the aim of this article is to propose a more complete view of the consequences of the heritage strategy for brands and consumers by exploring how consumers perceive a brand heritage experience and by identifying potential resistances that may emerge during their visits. In consequence, this research examines the features of a brand heritage experience through extended case studies in two brand museums with narratives of 47 visitors. By unpacking a brand heritage experience, the study highlights its acceptance by a majority of visitors as a real heritage experience since they give scientific, authentic and aesthetic values to the industrial and commercial features of the brand. However, some visitors do not accept - partially or totally - the brand as part of the heritage corpus insofar as they exhibit skepticism or even reject the experience.

Keywords: brand heritage experience; heritage; resistance; brand museums; branding 


\section{Introduction}

'Our brands always have had a sense of innovation and the abundance of our collections is the proof. Our role in The House of the Laughing Cow is to preserve this heritage for the future generations, to continuously collect new objects and also to convey this piece of our common history to a growing audience.'

The quote above, [http://www.lamaisondelavachequirit.com/en/discover/the-laughing-cow-andhis-collection/] touting The Laughing Cow's brand museum, aptly demonstrates a company's strategy aiming at melding branding with heritage. Indeed, like the Laughing Cow, an increasing number of firms offer an immersion within the universe of their brand through a heritage-like experience whose brand museum is a special case (Hollenbeck, Peters, \& Zinkhan, 2008).

Such an immersion in a brand heritage experience is the result of the interaction between two types of experience. On the one hand, as suggested by the presentation of The House of the Laughing Cow, consumers are immersed in a brand experience during which they are exposed to a number of assets of the brand: its history, its expertise or its know-how (Urde, Greyser, \& Balmer, 2007). On the other hand, consumers have a heritage experience which implies specific features. Indeed, as a patrimony constituted by the society or a social group, a heritage artifact is an extraordinary object that is out of market relationships (Gauchet, 2005). Building on a set of collective accepted values, heritage objects are at the heart of identity transmission and construction mechanisms (Otnes \& Maclaren, 2007).

While heritage strategies have previously been analyzed in marketing (Urde, Greyser, \& Balmer, 2007; Pecot \& De Barnier, 2017), this literature tends to consider that the use of heritage has consequences that are necessarily positive. Said differently, scholars assume that heritage strategies have the ability to systematically create value for both brand and customers. In this 
paper, we argue that a brand heritage experience is also likely to generate some resistances among consumers. Indeed, a brand heritage experience is a complex experience based on the overlap between the commercial world (the brand original world) and the non-market world (the heritage universe), which may create discordant interactions (Debary, 2004). While the heritage universe can integrate a commercial dimension as illustrated by contemporary museums that develop an active marketing policy, a brand heritage experience leads more fundamentally to consider the brand as an object of heritage. Consumers are then likely to identify contradictions in this ambivalent experience and thus develop some forms of resistance (Peñaloza \& Price, 1993; Roux, 2007; Mani \& Chouk, 2017). In consequence, the objective of this article is to explore how consumers perceive such an experience and to identify potential resistances that may emerge during the experience, thus proposing a more complete view of the consequences of heritage strategy for brands and consumers.

To investigate our research question, we examine the brand heritage experience in two French brand museums - the Fallot Mustard Mill and The House of the Laughing Cow - with direct observation and 47 narratives of visits. Since brand museums are specific cases of brand heritage experience, they offer an ideal empirical setting to study the importance of heritage and its implementation in a brand context. The results show that a large majority of visitors legitimize the experience in brand museum as a real heritage experience since they give scientific, authentic and aesthetic values to the industrial and commercial features of the brand. However, these three dimensions of the brand heritage experience also provoke resistances for some consumers who question the heritage nature of the experience, albeit with varying degrees. While some visitors undoubtedly adhere to this heritage experience, others may develop skepticism, or even a definitive rejection. A review of the literature, our methodology and 
findings follow. We conclude with a discussion of the theoretical contributions, managerial implications and suggestions for future research of the article.

\section{Literature review}

\section{Heritage experience and heritage brand}

Previous literature, particularly in tourism, has addressed the experiential benefits that consumers derive when visiting a heritage site (Goulding, 2001; Chronis, 2005; Massara \& Severino, 2013; Kempiak et al., 2017). First, heritage experiences have been shown to be authentic experiences, that is, experiences of genuineness, reality and truth (Grayson \& Martinec, 2004). In an authentic experience, objects and places play an important role (Goulding, 2000). Indeed, because of their non-denatured nature (Andriotis, 2011; McDonald, 2011), heritage objects physically embody History and constitute a bridge between the past and the present (McDonald, 2011). Second, previous literature has also highlighted the importance of the intellectual stimulation for visitors (Prentice, Guerin, \& McGugan, 1998; Smith, 2006; Falk et al., 2012). When immersed in a heritage experience, consumers are led to discover, learn and extend their knowledge, which is a source of excitement and pleasure (Calver \& Page, 2013). This intellectual stimulation leads them to reinterpret the narrative proposed by the heritage site (Chronis \& Hampton, 2008) and to develop their own experience of the past (Beeho \& Prentice, 1997). Third, heritage experiences are also aesthetic experiences in essence and visitors appreciate the heritage not only for what it represents, but also for its beauty and aesthetics (Goulding, 2000; Chronis, 2005). Overall, this stream of research suggests that the consumption of heritage elements can have a significant impact on individuals in terms of attachment and loyalty with the heritage site (Chen \& Chen, 2010). Heritage experiences have also an identity impact on consumers. This impact may happen 
both at the individual level, which leads people to redefine themselves after the experience (Poria, Butler, \& Airey, 2003; Gonzalez, 2008), and at the collective level since heritage facilitates cohesion and solidarity within communities (Park, 2010). This stream of research has been able to identify dissonant elements in the experience such as a simulated authenticity (Chhabra, Healy, \& Sills, 2003) or the commodification of heritage (Goulding, 2000). However, there is no clear conclusion concerning the negative impact of these conflicting elements on consumers' experience. In consequence, the literature has developed a homogeneous and biased vision of heritage experience, considering it as necessarily positive for the consumers.

In parallel, another stream of research studies the intrinsic properties of the brand as a heritage component of a company. This approach is based on brand equity models (Keller, 1993) as well as works adopting organizational analysis (Melewar, 2003). In this perspective, the brand's heritage dimensions are seen as a value-creating strategic asset, facilitating the development of sustainable competitive advantages and strengthening relationships with all stakeholders (Hudson, 2011). Heritage brand (or historic brand) is assimilated to a dimension of the brand identity with its own characteristics (Wiedmann et al., 2011). According to Urde, Greyser and Balmer (2007), a heritage brand has five major components: a company with a track record for delivering value to all stakeholders over time, a company with longevity, a company with long-held fundamental values, a company that uses symbols of the past in its communication and a company for which history is important to its identity. Based on these elements, Pecot and De Barnier (2017) have identified two types of heritage brands: on the one hand, familiar, customer-oriented, omni-temporal and pioneering brands, and, on the other hand, aristocratic, past, product-oriented and prestigious brands. Through central values and clearly identifying symbols, a heritage brand has the ability to continuously create value for the 
customer over time (Burghausen \& Balmer, 2008; Hakala, Lätti, \& Sandberg, 2011; Hudson, 2011). Even if the perception in the present of historical elements relating to a heritage brand can evolve over time, depending on the context (Sørensen, Korsager, \& Heller, 2018), the use of heritage brands leads to positive outcomes. For Balmer and Chen (2017), heritage brands have a positive influence on consumer satisfaction while for Rose et al. (2016), brand heritage positively impacts purchase intention, inspires positive emotions and trust, and facilitates brand attachment and commitment. Pecot et al. (2018) show that these positive outcomes apply to both established companies and new entrants. A heritage brand is therefore a major challenge for companies, keen to develop a strong brand, which may belong to the collective unconscious.

However, while both the heritage experience and the brand heritage literatures suggest that the consequences of emphasizing the heritage are consistently positive for the brand and consumers, we argue that such an association may also be perceived as discordant for consumers, thus creating some resistance.

\section{Brand heritage experience and the potential emergence of consumer resistance}

The practice of presenting everyday objects as a part of heritage has been increasing exponentially for many years, leading some to speak of a 'heritage crusade' (Lowenthal, 1998; Heinich, 2011). This process also affects brands looking to promote their history and heritage. By offering a brand heritage experience, especially through brand museums (Hollenbeck et al., 2008), the brand seeks to be recognized as part of the heritage corpus, thus claiming collectively admitted values through a temporal and topographic rooting (Lowenthal, 1998). The temporal anchoring allows managers to present the brand as a point of reference in the society (Waitt, 2000) while the topographic anchoring allows them to represent the brand as a symbol of a 
territory (Park, 2010). However, the process of transforming brands into a heritage artifact through a consumer experience is not obvious and may generate resistance among consumers (Debary, 2004; Urde, Greyser, \& Balmer, 2007).

Previous research has shown that, confronted with marketing tactics they consider inappropriate, consumers can develop resistant behaviors (Peñaloza \& Price, 1993). Consumer resistance can be defined as "a motivational state leading to variable manifestations of opposition and which is triggered by certain factors linked to corporate behaviors and marketplace practices" (Roux, 2007, p. 69). As this definition suggests, resistance originates from the perception of dissonant elements in a situation. More precisely, resistance appears when consumers are confronted with a stimulus that challenges pre-established representations (Roux, 2007), thus creating contradictions (Holt, 2002). Consumer resistance can result in a lack of adherence and an impossibility to accept what is presented (Fournier, 1998; Roux, 2007). Fournier (1998) suggests that consumer resistance activities vary along a continuum of adverse behaviors, ranging from simple avoidance of specific brands to skepticism and to more hostile actions. Skepticism can be defined as a defensive mental device (Dobscha, 1998; Odou \& de Pechpeyrou, 2011) which implies doubt, distrust and suspicion against specific marketing stimuli (Roux, 2008). In a more extreme form of resistance, consumers may completely reject the offer (Lee et al., 2011; Mani \& Chouk, 2017), which can be reflected in the creation of a negative word-of-mouth (Woisetschläger, Haselhoff, \& Backhaus, 2014) or in boycotts (Kozinets \& Handelman, 1998).

In the case of a brand heritage experience, consumers may indeed have representations of what a traditional heritage experience is, that may differ from what a brand can offer. The uneasy and even discordant interaction between brand and heritage can thus raise questions about such 
an association (Debary, 2004). Through a heritage experience, managers seek to convey the brand history and know-how from generation to generation, and to redefine the brand out of its original commercial world. But because brands are commercial objects by nature, such an orientation may lead consumers to question the association between branding and heritage. Moreover, given the socially constructed nature of heritage that does not exist a priori (Lowenthal, 1998), its content may be subject to debate or disagreement (Pecot \& De Barnier, 2017). In particular, consumers may not define brand heritage in the same way as managers (Rindell et al., 2015). This difference of perception may then lead to the emergence of various degrees of resistance during the brand heritage experience by some consumers who may doubt about the legitimacy of a brand to be redefined as a heritage object.

In this context, this article aims to understand what are the main structuring dimensions of a brand heritage experience from the consumer point of view and to identify potential resistances that may emerge during this experience.

\section{Methodology}

\section{Data collection}

To understand the brand heritage experience, we conducted two case studies. According to Yin (2013), a case study can be defined as 'an empirical inquiry that investigates a contemporary phenomenon within its real-life context, especially when the boundaries between phenomenon and context are not clearly evident' (p. 13). In our approach, the use of case studies was deemed appropriate because we needed both a contextual sense (Miles, 1979) and a holistic picture of the issue (Gummesson, 2000). More precisely, we decided to investigate two brand museums - the 'Fallot Mustard Mill' and the 'House of the Laughing Cow' - because brand museums offer an 
ideal empirical setting to study the importance of heritage and its implementation in a brand context (Hollenbeck et al., 2008). Fallot is a family business created in Burgundy (France) which produces mustard in a traditional way. Opened in 2003, its museum offers a tasting area and two distinct tours dedicated to the techniques and traditions associated with mustard and its history.

The House of the Laughing Cow is a French brand specialized in cheese, celebrated in a 27,000square-foot museum (in Lons-le-Saunier, France) since 2009, where visitors can discover the history of the brand, its evolution, and its multiple representations. The two brand museums were selected according to similarity and variety criteria in order to observe regularities in the heritage brand experience. Thus, we chose to analyze two brands belonging to the agri-food industry, but presenting a completely different positioning, notoriety, history and territorial anchorage. Fallot is a handcrafted mustard brand which values its traditional know-how with a product deeply rooted in the Burgundy and dedicated to connoisseurs. Conversely, the Laughing Cow is an industrial cheese brand with a worldwide presence. The case study represents a research method in which contextualization (Stake, 1995) and complexity (Yin, 2013) are the foundations of a mode of contribution unique to knowledge in a given field. Consequently, choosing such different contexts allow us to give a more generalizable character to the processes and mechanisms that we study, avoiding to lock them into an idiosyncratic logic (Becker, 1990).

As recommended in such a methodology, we collected data from multiple sources in a sequential two-step approach (Flick, 2013). In a first step, three types of information were collected by the three researchers : (1) we analyzed several documents (information and commercial leaflets, museum maps, press releases, websites) to capture the way the two firms present and communicate about the brand heritage experience proposed in the museums; (2) we conducted interviews with the managers of the two museums to understand how the museums 
have been designed by the brands and their goals; (3) we used ethnographic techniques in order to gain insights about the heritage experience in the real setting and by participating in 13 observation sessions in the two museums (Arnould \& Wallendorf, 1994). The aim of this first step was to gain an in-depth understanding of the context. It helped us to understand and analyze the visitors' experience collected through narratives in a second step.

Those consumers' narratives combine field logs and guided introspection and were collected after the visit (Wallendorf \& Brucks, 1993). More precisely, we recruited participants at the beginning of a visit. They received a notebook and pen to take notes during the visit about their thoughts, feelings, and moments of surprise and enjoyment. We also asked them to take photographs to help them remember the experience. After the visit, we provided participants with a quiet area and writing desk. The informants were asked to complete their narratives about their visit in the brand museum using their notes and photographs but no instructions about what to focus on were provided. Contrary to depth interviews, the interest of consumer narratives is that individuals can take notes throughout the visit, thus ensuring vivid memory of the experience. 47 narratives ( 23 related to visits of the House of the Laughing Cow and 24 related to visits of the Fallot Mustard Mill) have been written with the final sample comprised of a diverse group of participants in terms of gender and occupation but also in terms geographical origins. Indeed, since the brand heritage experience can include references to local heritage, visitor perceptions could vary greatly between consumers from the brand's place of origin and those from farther away. In our sample, only 11 respondents came from the brand's place of origin.

\section{Data analysis}


Consumer narratives were analyzed by the three researchers in a systematically comparative (Bertaux, 1997) and hermeneutics perspective (Spiggle, 1994; Thompson, 1997; Arnould \& Thompson, 2005). By using an iteration process and through a progressive abstraction, data were analyzed in a back-and-forth between individual and collective interpretation stages with the aim of obtaining a shared understanding of the heritage experience in a brand museum and neutralizing individual subjectivity (Goulding, 2005). Disagreements between the three researchers were all settled after discussion and reformulation of conclusions while bearing in mind the objective to obtain a thick description of both cases (Hollenbeck et al., 2008; Borghini et al., 2009).

More precisely, the analysis was performed in three steps (see Appendix 1). First, we examined the singular information for each case and we manually coded the narratives. We attributed labels to each of the structuring dimensions at the heart of the brand heritage experience (scientificity, authenticity, aesthetics). Those units of meaning were always accompanied by the original transcriptions in order to identify the mechanisms that embody them (collections, rooms, educational supports, scenography, guide...). Second, we focused on visitors' interpretations of the different dimensions and the operational mechanisms that give them substance. We characterized the points of resistance as well as the devices at their origin for each dimensions of the experience. While consumers value most of the brand heritage experience, visitors' narratives also reveal that some aspects could be negatively perceived because of incoherence, incongruence and dissonance during the brand heritage experience. Third, a cross-sectional analysis of the two cases was performed. By comparing the divergences and the convergences between the dimensions identified within each of the situations, we were 
able to switch from a "local" analysis to "global" considerations and to define more inclusive categories in order to obtain a higher level of generalization.

\section{Findings}

The analysis of the narratives reveals that the brand heritage experience is based on scientific, authentic and aesthetic dimensions. We now explore and document these characteristics as well as the different forms of resistance associated with each of them.

\section{Between adherence and suspicion towards the brand's scientific discourse}

Each brand museum initiates a heritage process through a scientific orientation that serves as a source of intellectual stimulation for visitors, encouraging discoveries (Falk et al., 2012; Prentice, Guerin, \& McCugan, 1998; Smith, 2006). Visitors to the Fallot Mustard Mill and the House of the Laughing Cow see this dimension by experiencing proof of these museums' respective long-established expertise, which visitors associate with the production of scientific knowledge (Kozinets, 2008). As our participant Daniel, who had just toured the Fallot museum, said:

We discover behind a window the real place of production with the employees, the machines, the materials...It's really great to go behind the scenes, to see the mills crush the seed, the dough pass in the vats, to see packagings, pots, cartons ... I'm very surprised to discover all this, and above all to learn a lot of things!

The intellectual stimulation accrues through this demonstration of specific skills. Additionally, the museums' technology, manufacturing processes, and marketing materials through the eras are all on display as living evidence of the brand's expertise, as noted by our participant Pauline, a visitor at the House of the Laughing Cow: 
The showcases are organized chronologically showing us the evolution of the brand, the logos, the marketing campaigns. Everything is done to better understand the history of the brand. I have learned many things about the brand that I had no idea about before and that's the point of this visit.

For some visitors, the heritage legitimacy of the brand is also expressed through its concern for transparency and sincerity. Beyond the information they reveal, brand managers want through the museum to move away from a simple commercial discourse, as suggested by Anne-Lucie about the Laughing Cow:

The guide is very available to answer questions without 'political cant'... I would say without a "brand message" or a kind of auto-promotion too persuasive. Her answers are very transparent about the product and the history of the brand. I noticed it twice in particular. About a question related to the ingredients of the Laughing Cow, she restored truth without circumventing clichés about the brand. She explained where this idea, sometimes still strong, that the Laughing Cow would be made with cheese wastes or cheese rinds comes from. And then, she detailed the real ingredients used in the production. There is really in the interest of transparency. By showing us how they do, they show that they are not just an industrial brand where we do not know what is inside. And concerning the history of the brand, she talked as much about the successes as about the failures of different advertising campaigns, different recipes...

Behind this transparency, visitors suggest that companies engage in actual, demanding historical processes, which in turn creates an aura of 'scientific expertise' in the exhibition, as perceived by Dominique, a visitor at the House of the Laughing Cow: 
The brand museum adopts a true historical perspective; they didn't try to hide historical conflict with 'La Vache Sérieuse'1 (a local competitor). This is history from a scientific perspective... that goes beyond the desire to serve their own interests.

Visitors of a brand museum not only learn about a brand product line, expertise, and history (Pecot \& De Barnier, 2017), they also experience a wider perception, rooted in place, nationality, and community, of time, for which the brand is ultimately an emblem (Riegl, 1982). Our participant Simon reported after his visit of the House of the Laughing Cow:

With the Laughing Cow, we have a century of history and of human behavior. When I discover the machines, the places, the old cellars, all the stuff that the brand has kept and exhibits, visitors can see History with a capital H because it's not anecdotal. It concerns Humanity.

As revealed by this quote, the evidence of the expertise is brought through the presentation of the brand history, the history of the founders, the secrets in terms of recipes, ingredients and modes of production, or even of the advertising creation which demonstrate the longevity and the rooting of the brand in the eating habits of the individuals. Through demonstration logic and providing access to knowledge, brand museums satisfy a key social function of the heritage experience: the creation and transmission of savant knowledge (Calver \& Page, 2013; Poria, Biran, \& Reichel, 2009), which establishes the brand itself firmly within the heritage sphere and the brandscape as a real museum.

However, while a majority of the participants recognize in their narratives the scientific orientation of the brand museums, some others seem to be more reserved or even critical about it and therefore question the intellectual dimension of the experience. According to them, brand

\footnotetext{
${ }^{1}$ i.e. 'The Serious Cow' by opposition with the Laughing Cow.
} 
museums are very different from real heritage museums because they merely expose truncated and incomplete scientific knowledge. This criticism is particularly present in Aline's narrative concerning the Fallot Mustard Mill:

Regarding production, there are panels on which it is noted "production of walnut mustard" but you never see the manipulations they do, you do not see any walnut. Are they already powdered? Do Fallot receive whole walnuts? What is the manipulation they do with them? (...) Then, at some point, the formula of the chemical reaction that gives the pungency to the mustard is noted on a wall. But if you have no background in chemistry, you do not understand anything! They do not provide any information at all while in a real museum, they would have explained it.

The fact that the brand does not show or explain everything leads Aline to question the scientific discourse of the structure and develop a kind of skepticism towards it. She finally opposes the totally transparent and pedagogical approach of a traditional museum to the relatively truncated information of a brand museum. This results in frustration and an inability to appropriate the proposed content. Some visitors may question the proffered information and the fragmentary aspects of exhibitions, and thus challenge the museum's scientific orientation.

Bruno, a visitor who is deeply immersed in the Laughing Cow brand and in its history, stated: In the exhibition, they show just a piece of the Laughing Cow while, for me, there is a richer and more impressive history. Just in France, there were between 4,000 and 5,000 Laughing Cow images that were in the boxes. There were pins and key rings. There were thousands of promotional items. What the museum shows, it's really not enough to fully understand the history of the Laughing Cow. But it is as an expert that I tell you that. I am 
not sure that the general audience will question the scientific foundations of the exhibition like me".

Resistance also appears when visitors regret a self-centered discourse on the brand. This discourse is considered as an instrumentalized one which serve the brand itself rather than a general knowledge about the brand's industry. Several visitors, such as Henry in the case of the House of the Laughing Cow, regrets this aspect:

On the one hand, the brand wants to highlight historical dimensions but they do not mention their competitors. If it was a real museum, they would have rather talked about the history of cheese, dairies, butter, cream... In this House, they only mention the Laughing Cow, even if it is their goal. It's too centered on the Laughing Cow. I think it has a more commercial side than a real testimony on the history of cheese to deepen knowledge on the topic.

These last two quotes suggest that the information transmitted by brand museums is not enough comprehensive and much too self-centered around the brands themselves. In the scientific logic of a traditional museum, the information should be much more exhaustive about the brand's business sector, the brand's competitors, their histories, their know-how, their differences, etc. This feeling of a lack of information can create a lack of adherence of the brand scientific discourse. That critical resistance is potentially dangerous because it can make visitors delegitimize the heritage character of the experience and associate it only with the lucrative objectives of the brand and not with the intellectual and scientific character of a traditional museum.

\section{Between acceptance and criticism of the brand heritage authenticity}


A brand heritage experience is also based on authenticity. Authenticity is expressed at brand museums through artifacts with a tangible and undeniable origin (Grayson \& Martinec, 2004; Hede et al., 2014). The objective authenticity is embodied by items weathered by time and use, and thus perceived as reference pieces, whether packaging, advertising, promotional items, or tools and machines, which are no longer seen as ordinary objects but rather as markers of history and time suited to a museum (Pecot \& De Barnier, 2017). Our participant Annie discussed the Museum Fallot exhibitions:

In the attic, we are in the middle of old machines, we discover the tools and the modes of production as they used to be. It's amazing to have kept all these things of the past and to be able to propose such a return in the past.

Authenticity is further supported by the reuse of historical sites of manufacture. Investing in such spaces allows to present the physical traces of the production activity (Xie, 2006), which make the location, objects, and the brand itself credible within biographical, cultural, and historical points of view (Benjamin, 1968). Our participant Chrystel reported on the site of the Fallot Mustard Mill:

It's very interesting to see that the museum is anchored in a city (Beaune) where the brand history began and that the brand converted rooms that were dedicated to the production into a museum. There are still marks of use on the wall and the floor. I like this link between the site's history, how it "was before" and now how the brand integrates this in a very modern process. There is a staging but of something that is true and right.

Based on an objective authenticity, some visitors experience a form of existential authenticity, viewing heritage from a romantic perspective (Kim \& Jamal, 2007). The original artifacts engender reverie, a perceived nostalgia for an idealized bygone era, combined with the 
reactivation of personal memories. A participant, Ines, recalled about the House of the Laughing

Cow:

In the first room of the first floor, I observed several objects on display: old advertising posters, old logos, and ancient cheese boxes... treasures dating back to the mid-twentieth century, and I really have a feeling of being transported in this post-war period. During the visit, I enjoyed imagining period scenes such as, for example, this all-metal 'dinette' [toy] that little girls could earn through brand contests. It also reminds me of my childhood.

The identification of an existential authenticity meets the emotional aspirations of individuals, promoting a pleasant experience (Brown, Kozinets, \& Sherry, 2003). The visit of the brand museum is thus registered in creative reconstruction and as a form of emotional heritage (Heinich, 2011). In the context of brand museums, authenticity is thus multifaceted. It encourages brand engagement as it preserves of the integrity of a brand's origins (Prentice, 2001). Based on a reproduction of the past, the perception of objective authenticity may enable visitors to accept the veracity of an exhibition (Goulding, 2000).

However, while real vestiges are exposed, the brand museum can also present different reconstructed tools, spaces (reproductions of old grocery stores, traditional attic or cellars) and scenes from the brand life (through recorded sounds of old production machines, videos...) because the original ones do not exist anymore or because those tools are able to facilitate the immersion of the visitors in the brand heritage experience (Baudrillard, 1981). Hence, brand museums can use simulated authenticity (Chhabra, Healy, \& Sills, 2003; Leigh, Peters, \& Shelton, 2006). But when they do it without saying it explicitly to visitors, managers take the risk of creating confusion between what would be true and what would be factice in the museum. 
Visitors' narratives express clearly theses ambiguities. Some mechanisms are evaluated very positively but others very critically. This is the case of the first room of the House of the Laughing Cow. For Maud, this room illustrates the authenticity of the brand:

The visit starts in the old cellars where the cheese was made at the time. Authenticity is present everywhere in this room: the vaulted cellar, the exposed stone walls, wood, subdued light, black and white pictures. There are large cheese wheels that remind us of the usefulness of these cellars at the time. I really feel like I'm at the heart of the story of the Laughing Cow!

At the opposite, Anne-Lucie questions the authenticity of the House of the Laughing Cow and rejects it strongly:

The visit should begin where the origin cellars of the Laughing Cow were. By the way I am surprised to learn that it is in these cellars that the cheese was created in 1921 by Léon Bel under the name of Gruyère cream! The first space, presented as the historic cellar, is very deceptive because it looks nothing like an ancient cellar. I come closer to two cheese wheels and I see that there are buttons on which I can press to have comments. They are false!... I do not like the fake wheels put on the shelves. And the renovation seems to have removed all authenticity of the place. I feel like I'm in a reconstituted demonstration cellar! [...] I do not understand... Here everything is wrong!

The problem of authenticity can also affect the museum shop, which is an integral part of the visit and must convey the heritage values of the brand in a consistent way. When visitors perceive the items for sale as unrelated to the brand's values and to its territorial roots, the risk of misunderstanding is strong. For example, Fanette was negatively surprised when she discovered the objects available in the shop of the House of the Laughing Cow: 
Concerning the gift shop, I'm very disappointed. I admit that I did not really know what I was expecting, but maybe less "made in China" derivatives! It was all a bit of a mess, the Laughing Cow is everywhere from the office, to the kitchen and the clothes... We find everything and anything... but the Laughing Cow product is completely neglected. Even if you are in a museum it reminds me that I have to deal with a brand that wants to sell... and the exorbitant prices practiced remind that too! A cup with just the logo on it costs between 10 and 13 euros and a t-shirt between 15 and 20 euros. I have already bought souvenirs several times at the end of a museum visit, but it was always something that carried values, that embodied the museum and really ensured good value for money. So I'm wondering who would be willing to buy such unnecessary things at these prices?

Between the authenticity expected by visitors given their pre-established representations of a museum and the recreated, reconstructed, renovated and sometimes very quirky tools used by brand museums, deep dissonances may appear, creating a form of misunderstanding and, for some visitors such as Anne-Lucie, leading to the rejection of the experience. Since the early projections of the brand authenticity are centered on its craftsmanship, perceived in terms of sincerity and integrity (Athwal \& Harris, 2018), such resistance in visitors' experience can damage the heritage status of the brand, its legitimacy and replace it in a commercial sphere.

\section{Between appreciation and denial of the aesthetic nature of the brand heritage experience}

Our data underscore the importance of aesthetics in brand museum experience. Our participants were well aware that they experienced different artification processes related to both the museum location and its exhibits. The aesthetic experience associated with a museum location integrates the museum's architecture with the configuration of interior spaces through a meticulous scenography (e.g., spaces, lightings, colors, and materials), which creates a comprehensive 
experience (Joy \& Sherry, 2003; Rodner \& Kerrigan, 2014; Vukadin, Lemoine, \& Badot, 2016), as our participant Alain noted:

Aesthetically, the Fallot Mustard Mill is really fine. There is a contrast between the room where there are old tools with a rustic aesthetic where we sit on old cases and the modern room where the tour guide explains the brand's tradition. And when I hear about tradition, I prefer to sit on old cases. It's better than being in very modern seats. It's consistent.

The difficulty regarding the aesthetic dimension lies in the eminently subjective aspect of visitors' aesthetic perception. The choices of the managers can please the visitors and participate to the legitimization of the structures as a real museum like Morgane reports when she arrived in front of the entry of the House of the Laughing Cow:

I really enjoyed the building, it's not a neutral building, it's stylish, architecturally elegant, it impresses the visitors. I really feel like I'm entering in a heritage place and not in a simple store that sells Laughing Cow products. It was my biggest fear before starting the visit.

However, the same choices can also confuse visitors. It was the case for Julie when she discovered the House of the Laughing Cow:

When I arrived, I was surprised, intrigued and disappointed. On the parking of the House of the Laughing Cow I felt like being in front of a supermarket, or a warehouse, but not in front of a museum! I found the building very ordinary, simple, cold and ugly! Not a museum! I finally found a panel with the head of the Laughing Cow on a wall, between large grids, that told me I was finally in front of the museum and not in front of a factory. But I felt more transported into the world of an unhappy cow in an enclosure than in the 
world of the Laughing Cow! Once past the entry door, we arrived in a very bright, spacious, green, pleasant and relaxing space. However, I was a little bit lost, I got the impression that I was at an aquatic center or a private hospital. I cannot find the visual identity of the brand, nor the atmosphere of the ads. I cannot find the childish and colorful universe of the Laughing Cow I was expected.

While visiting a museum is often associated with values of aesthetics and escapism from the everyday life, this quote illustrates the questions and the skepticism generated by the discrepancy between this prior representation of a museum and the discovery of a brand museum highlighting another form of heritage. Beyond this problem of aesthetic perception - which is difficult to circumvent - such process of aestheticization leads visitors to experience objects beyond their original utilitarian and technical functions, providing a new aesthetic significance (Minkiewicz, Evans, \& Bridson, 2014). Visitors are invited to gaze in a contemplative and distanced way, as they might on pieces of art. Such was the case when a participant Magalie admired 'the first tin of The Laughing Cow [placed] in a showcase in the middle of the room like a relic, a piece of art'. Indeed, aestheticization can involve the brand product itself, as described by Maïté during her visit to the Fallot museum:

In the next room, in a dim light, I discovered a wall decorated with semi-transparent jars of mustard in a variety of colors - yellow, red, and orange. I was surprised to find such "an artwork" at that point in the museum visit. But I think it's well thought out and it's beautiful... jars of mustard that ultimately represent something like a contemporary painting. And since there are some seats aligned along the wall, I could sit down and admire the scene. 
However, in brand museums, aestheticization can also relate to tools and machines too. As our participant Antoine reported after his visit of the Fallot Mustard Mill:

The old machines in the attic are on display. So, we can consider them as art objects.

Before, this machine had another dimension, another utility. Of course, at the beginning, it was not a work of art. But since its historical value has increased, now it is an authentic account of the past and that it is emphasized and valued by Fallot; it changed its role and I look at it in a new light.

A majority of visitors enjoys the "beauty" of those objects, originally defined like industrial objects, but redefined as aesthetic artifacts in brand museums. However, resistance appears when it comes to the aestheticization of advertising materials. While some visitors appreciate the diversity of the heritage artifacts of the brand, thus emphasizing the richness and the beauty of these elements, other consumers do not accept the transformation of advertising items into art objects. The commercial nature of these elements can lead visitors to question their legitimacy as heritage artifacts. Laura raised this question during his visit in the House of the Laughing Cow:

This commercial dimension is felt when you see the presentation of ads and TV commercials. Museum officials can give them a historical dimension but it's still a commercial story to the advantage of the brand. What I mean is that these are just commercials when you think about it. It is inevitably questioning: does it really have its place in a museum?

This quote underlines the dissonance that can be created between the purpose of a market object and the heritage meanings that the brand wants to associate with it in the brand museum. It gives rise to a conflict of representations and meanings between the heritage world and the 
commercial world to which the brand belongs, and leads to the emergence of a "reflexive" resistance to a market logic (Roux, 2007). Despite this potential resistance, this aesthetic experience led some participants, particularly those who lived locally, to highlight the role of the brand museum as a space that can provide artistic resources and promote creation. Laetitia, a participant who lives in the Jura and has visited the House of the Laughing Cow, commented:

Clearly, for the locals, the House of the Laughing Cow offers a counterpoint to contemporary art museums that do not exist in the city. The brand museum serves as a resource for locals. I consider the House as a place where contemporary art is really valued.

These results show that a majority of our participants lived an aesthetic experience during their visit, whether it was a pleasant or an unpleasant one. They also highlight that consumers do not systematically categorize every pieces of the brand museums in the field of art.

Overall, the analysis of the narratives allowed us to identify three structuring dimensions of the brand heritage experience. Within each dimension, resistance could appear during the brand heritage experience.

\section{Discussion}

\section{Theoretical contributions}

By investigating the brand heritage experience in a brand museum, this article adds to the literature dedicated to heritage. First, by unpacking a brand heritage experience, we highlight simultaneously its acceptance by some visitors as a real heritage experience and the demonstration of some forms of resistance by other visitors who question or do not accept partially or totally - the brand as part of the heritage corpus. On one side, a majority of visitors 
consider the experience in brand museums as a heritage experience in its own right, enjoying its scientific, authentic and aesthetic nature even if it is based on mechanisms and features that are specific to the brand's commercial and industrial universe: production site as museum place, industrial tools or products as artistic artifacts, commercial and marketing materials as evidences of the brand's history. On the other side, some visitors contest the registration of the brand in the heritage sphere and exhibit some resistance during the experience. They question, dislike or even reject some aspects of the brand heritage experience and they have in consequence more or less reluctance to accept the brand heritage experience as a real heritage experience. Our data also reveal that these resistances have been particularly reported in the context of the House of the Laughing Cow. Because this brand is a world-wide brand, associated with an industrial production and an extensive distribution, it is more difficult to defend its know-how, its expertise, its authenticity and to immerse visitors in an aesthetic experience. On the contrary, the fact that Fallot uses a more homemade production with a quality positioning and a more selective distribution generates less resistance (or of less intensity) to its heritage experience. However, many devices are similar to those used in the House of the Laughing Cow. Beyond these differences, our results provide here a nuanced vision of a brand heritage experience and offer an interesting counterpoint to the marketing literature which systematically defends the idea that heritage is a source of significant value creation for the brand and/or for consumers (Hakala, Lätti, \& Sandberg, 2011; Wiedmann et al., 2011; Pecot et al., 2018). Contrary to this body of literature, our research highlights that the registration of brands in the heritage universe is not obvious and can create resistance from visitors. As a result, for these consumers, the experience in brand museum has low (or even no) heritage value. In this context, our findings lead to point 
out the critical role of consumers in the (co)creation of value associated with heritage (Pecot \& De Barnier, 2017).

Second, beyond the identification of negative perceptions from visitors due to the presence of brand in the heritage corpus, we identify and characterize different forms of resistance in the heritage context. A first form of resistance leads to skepticism towards the brand heritage experience. Visitors perceive dissonant elements during the experience which clash with their prior representations of heritage (Roux, 2007; Cherrier, 2009). As the data indicate, several visitors question the nature of the knowledge transmitted by the brand museum, highlighting partial and biased presentations or displays exclusively focused on the brand and for the benefit of the brand. Some visitors also contest the authentic nature of the brand heritage experience by underlying the simulated nature of what is exposed. Finally, some visitors note a dissonant aesthetic experience in contrast to traditional heritage experiences and also the commercial, ordinary and in consequence non-artistic and non-aesthetic nature of the displayed objects. Visitors' resistance is triggered by factors related to practices or discourse perceived as dissonant (Roux, 2007). They exhibit in consequence some difficulties to accept - entirely - the heritage brand experience as a real experience and develop a form of skepticism (Dobscha, 1998; Odou \& De Pechpeyrou, 2011). However, they do not reject it entirely. By contrast, a second form of resistance leads to rejection of the heritage brand experience (Woisetschläger, Haselhoff, \& Backhaus, 2014). Triggered likewise by some dissonant elements during the experience, some visitors contest more radically the presence of a brand in the heritage sphere. They devaluate the experience, do not accept the possibility to consider brand as heritage object and bring it back to the commercial universe. They perceive an ontological conflict to associate the brand with the 
heritage sphere. The identification of these two forms of resistance echoes Fournier's (1998)

hypothesis who assumes the existence of a spectrum of forms of resistance along a continuum.

\section{Managerial implications}

This study suggests that managers should be aware of the resistance that may emerge during the brand heritage experience and identify its different sources in order to better understand and prevent it, even if it seems difficult to avoid any kind of resistance given the nature of the experience. Indeed, resistance does not originate only from misunderstandings or inconsistencies associated with heritage brand experience. It can also be related to previous experiences of the visitor with the brand, to his/her prior image and intimacy with the brand and pre-established representations of heritage. Nevertheless, some precautions can be taken to reduce the potential resistances during the visit and to anchor and legitimate the brand heritage experience in the heritage sphere.

First, at the stage of the brand heritage experience's design, our research underlines the importance to develop a heritage experience as consistent as possible. In consequence, to be legitimate as a real heritage experience, the brand heritage experience must be intentionally designed for this purpose; otherwise it will remain a pure commercial experience. In the case of brand museums, managers need to design it as real museum spaces. In this context, a pitfall to avoid is to design a brand museum as a flagship store and to propose a commercial experience under the label "brand museum". If consumers believe that the brand is developing this kind of structure for instrumental purposes (i.e. immediate commercial purposes), their perception of heritage brand experience is likely to be negative with, in consequence, no heritage value creation. In terms of features, architecture, ambience and design, along with discourse, displays 
and activities, must all convey heritage properties in order to immerse visitors in a full heritage experience, making them feel unexpected emotions for a brand (Vukadin, Lemoine, \& Badot, 2016). Here a pitfall to avoid is to propose inauthentic or artificial features, to develop selfcentered discourse or to present historical facts exclusively for the benefit of the brand. There is an important risk to deteriorate the perception of the brand heritage experience.

Second, the registration of the brand heritage experience into the heritage sphere can be supported through mediation devices usually mobilized in the heritage sphere. For instance, the use of audio-guides, guided tours, mobile applications or touch tablets can help the transmission of knowledge and reduce the potential perception of dissonant elements that may emerge more easily if the visitor is left alone during the experience. Outside the museum, brands can also mobilize online devices before and/or after the experience such as websites offering databases of digitized works, information notices or presentation folders on exhibitions. All these devices deployed in situ or online can allow managers to highlight the benefits usually associated with heritage experiences: intellectual stimulation and acquisition of knowledge, search for authenticity and aesthetic value. By giving meaning to the brand heritage experience, they can reduce potential differences between the visitors' prior representations and the brand heritage experience, thus avoiding the emergence of resistance.

\section{Conclusion}

In this article, we characterize the brand heritage experience and we document a nuanced understanding of what is a brand heritage experience, especially by highlighting the existence of resistance. Because of the exploratory and contextual nature of this study, several avenues for further research can be suggested. 
First, we conducted two case studies in two brand museums associated with the agri-food industry to analyze and compare the brand heritage experiences. The exploration of other brand museums in other industries such as automobiles or watches - in which brand museums are massively deployed - would allow to assess the generalization of the mechanisms identified during a brand heritage experience (Becker, 1990). Research could also extend the analysis of brand heritage experience in other contexts. The exploration of flagship stores using heritage technologies such as luxury stores (Joy et al., 2014; Dion \& Borraz, 2015; Logkizidou et al., 2018) or the investigation of blockbuster exhibits dedicated to brands in traditional museums (Rodner \& Preece, 2015) could be interesting settings to identify some forms of consumer resistance to the presence of brand in the heritage world.

Second, this research leads to the identification of resistance during the brand heritage experience, but we collected exclusively narratives from people who decided to visit freely a brand museum, that is, who are a priori not in resistance towards the presence of brands in a heritage context. To have a more fine-tuned understanding of resistance mechanisms in a heritage context (i.e. avoidance, boycott, negative word-of-mouth), it could be interesting to interview consumers who adopt a more radical and critical attitude toward the presence of brand in the heritage sphere. In parallel, further research could investigate whether the emergence of resistance is actually greater in heritage experience dedicated to industrial and worldwide brands in contrast to homemade and local brands.

Third, through narratives, we chronicle the existence of resistance from some visitors of brand museum. However, our exploratory qualitative approach does not allow us to identify individual factors that could explain the acceptance or resistance of the brand heritage experience. As underlined by previous studies (Goulding, 1999; Pecot \& De Barnier, 2017), all 
consumers do not have the same interest for heritage according to their level of education, their level of knowledge in history, their age or their geographical origin (in resonance with the brand's place of origin). It may also be relevant to take the consumer - brand relationship (previous knowledge, attachment, preference) into account. In consequence, it would be interesting to identify more precisely the profiles of consumers who are likely to accept or reject a brand heritage experience.

\section{References}

Andriotis, K. (2011). Genres of heritage authenticity: Denotations from a pilgrimage landscape. Annals of Tourism Research, 38(4), 1613-1633. doi: 10.1016/j.annals.2011.03.001

Arnould, E.J., \& Thompson, C.J. (2005). Consumer culture theory (CCT): Twenty years of research. Journal of Consumer Research, 31(4), 868-882. doi: 10.1086/426626

Arnould, E.J., \& Wallendorf, M. (1994). Market-oriented ethnography: interpretation building and marketing strategy formulation. Journal of Marketing Research, 31(4), 484-504. doi: $10.2307 / 3151878$

Athwal, N., \& Harris, L.C. (2018). Examining how brand authenticity is established and maintained: the case of the Reverso. Journal of Marketing Management, 34(3-4), 347-369. doi:10.1080/0267257X.2018.1447008 doi.org/10.1080/0267257X.2018.1447008

Balmer, J.M.T., \& Chen, W. (2017). China's Brands, China's Brand Development Strategies and Corporate Brand Communications in China. In: Balmer J.M.T., Chen W. (eds) Advances in Chinese Brand Management. Journal of Brand Management: Advanced Collections. Palgrave Macmillan, London, 19-47. doi: 10.1057/978-1-352-00011-5_2.

Baudrillard, J. (1981). Simulacra and simulations. Ann Arbor, MI: University of Michigan Press.

Becker, H.S. (1990). Generalizing from Case Studies, in E.W. Eisner and A. Pecking (eds.) Qualitative Inquiry in Education: The Continuing Debate. New York/London: Teacher's College Press, 233242.

Beeho, A.J., \& Prentice, R.C. (1997). Conceptualizing the experiences of heritage tourists: A case study of New Lanark World Heritage Village. Tourism Management, 18(2), 75-87. doi: 10.1016/S02615177(96)00103-3

Benjamin, W. (1968). Illuminations: Essays and reflections. New York, USA: Schocken Books. 
Bertaux, D. (1997). Les récits de vie. Perspectives ethnosociologiques. Paris, France: Nathan.

Borghini, S., Diamond, N., Kozinets, R.V., McGrath, M.A., Muniz, Jr A.M., \& Sherry, Jr J.F. (2009). Why are themed brandstores so powerful? Retail brand ideology at American girl place. Journal of Retailing, 85(3), 363-375. doi: 10.1016/j.jretai.2009.05.003

Brown, S., Kozinets R.V., \& Sherry, Jr J.F. (2003). Teaching old brands new tricks: retro branding and the revival of brand meaning. Journal of Marketing, 67(3), 19-33. doi: 10.1509/jmkg.67.3.19.18657

Burghausen, M., \& Balmer, J.M. (2014). Corporate heritage identity management and the multi-modal implementation of a corporate heritage identity. Journal of Business Research, 67(11), 2311-2323. doi: 10.1016/j.jbusres.2014.06.019

Calver, S.J., \& Page, S.J. (2013). Enlightened hedonism: Exploring the relationship of service value, visitor knowledge and interest, to visitor enjoyment at heritage attractions. Tourism Management, 39, 23-36. doi: 10.1016/j.tourman.2013.03.008

Chen, C.F., \& Chen, F.S. (2010). Experience quality, perceived value, satisfaction and behavioral intentions for heritage tourists. Tourism Management, 31(1), 29-35. doi: 10.1016/j.tourman.2009.02.008

Cherrier, H. (2009). Anti-consumption discourses and consumer-resistant identities. Journal of Business Research, 62(2), 181-190. doi:10.1016/j.jbusres.2008.01.025

Chhabra, D., Healy, R., \& Sills, E. (2003). Staged authenticity and heritage tourism. Annals of Tourism Research, 30(3), 702-719. doi: 10.1016/s0160-7383(03)00044-6

Chronis, A. (2005). Co-constructing heritage at the Gettysburg storyscape. Annals of Tourism Research, 32(2), 386-406. doi: 10.1016/j.annals.2004.07.009

Chronis, A., \& Hampton, R.D. (2008). Consuming the authentic Gettysburg: How a tourist landscape becomes an authentic experience. Journal of Consumer Behaviour: An International Research Review, 7(2), 111-126. doi.org/10.1002/cb.241

Debary, O. (2004). Deindustrialization and museumification: From exhibited memory to forgotten history. The Annals of the American Academy of Political and Social Science, 595(1), 122-133. doi: $10.1177 / 0002716204266630$

Dion, D., \& Borraz, S. (2015). Managing heritage brands: A study of the sacralization of heritage stores in the luxury industry. Journal of Retailing and Consumer Services, 22, 77-84. doi: 10.1016/j.jretconser.2014.09.005

Dobscha, S. (1998). The lived experience of consumer rebellion against marketing, in NA - Advances in Consumer Research, vol.25, Eds. J.W. Alba \& W. Hutchinson, Provo, UT: Association for Consumer Research, 91-97. 
Falk, J.H., Ballantyne, R., Packer, J., \& Benckendorff, P. (2012). Travel and learning: A neglected tourism research area. Annals of Tourism Research, 39(2), 908-927. doi: 10.1016/j.annals.2011.11.016

Flick, U. (2013). The SAGE handbook of qualitative data analysis. London: Sage Publications Ltd.

Fournier, S. (1998). Consumer resistance: societal motivations, consumer manifestations, and implications in the marketing domain, in J.W. Alba and J.W. Hutchinson (Eds.), Advances in Consumer Research, 25, Provo, Utah, Association for Consumer Research, 88-90.

Gauchet, M. (2005). Le Désenchantement du monde. Une histoire politique de la religion. Paris, France: Gallimard.

González, M.V. (2008). Intangible heritage tourism and identity. Tourism Management, 29(4), 807-810. doi: 10.1080/1743873X.2017.1384478

Goulding, C. (1999). Heritage, nostalgia, and the "grey" consumer. Journal of Marketing Practice: Applied Marketing Science, 5(6/7/8), 177-199. doi: 10.1108/EUM0000000004573

Goulding, C. (2000), The commodification of the past, postmodern pastiche, and the search for authentic experiences at contemporary heritage attractions. European Journal of Marketing, 34(7), 835-853. doi: 10.1108/03090560010331298

Goulding, C. (2001). Romancing the past: heritage visiting and the nostalgic consumer. Psychology \& Marketing, 18(6), 565-592. doi: 10.1002/mar.1021

Goulding, C. (2005). Grounded theory, ethnography and phenomenology: A comparative analysis of three qualitative strategies for marketing research. European Journal of Marketing, 39(3/4), 294-308. doi: 10.1108/03090560510581782

Grayson, K., \& Martinec, R. (2004). Consumer perceptions of iconicity and indexicality and their influence on assessments of authentic market offerings. Journal of Consumer Research, 31(2), 296312. doi: $10.1086 / 422109$

Gummesson, E. (2000). Qualitative methods in management research. Thousand Oaks, CA: Sage.

Hakala, U., Lätti, S., \& Sandberg B. (2011). Operationalizing brand heritage and cultural heritage, Journal of Product and Brand Management, 20(6), 447-456. doi: 10.1108/10610421111166595

Hede, A.M., Garma, R., Josiassen, A., \& Thyne, M. (2014). Perceived authenticity of the visitor experience in museums: Conceptualization and initial empirical findings. European Journal of Marketing, 48(7/8), 1395-1412. doi: 10.1108/ejm-12-2011-0771

Heinich, N. (2011). The making of cultural heritage. The Nordic Journal of Aesthetics, 22(40-41), 119128. doi: 10.7146/nja.v22i40-41.5203 
Hollenbeck, C.R., Peters, C., \& Zinkhan, G.M. (2008). Retail spectacles and brand meaning: Insights from a brand museum case study. Journal of Retailing, 84(3), 334-353. doi: 10.1016/j.jretai.2008.05.003

Holt, D.B. (2002). Why do brands cause trouble? A dialectical theory of consumer culture and branding. Journal of Consumer Research, 29(1), 70-90. doi: 10.1086/339922

Hudson, B.T. (2011). Brand heritage and the renaissance of Cunard. European Journal of Marketing, 45(9/10), 1538-1556. doi: 10.1108/03090561111151880

Joy, A., \& Sherry Jr, J.F. (2003). Speaking of art as embodied imagination: A multisensory approach to understanding aesthetic experience. Journal of Consumer Research, 30(2), 259-282. doi: $10.1086 / 376802$

Joy, A., Wang, J.J., Chan, T.S., Sherry Jr, J.F., \& Cui, G. (2014). M (Art) worlds: consumer perceptions of how luxury brand stores become art institutions. Journal of Retailing, 90(3), 347-364. doi: 10.1016/j.jretai.2014.01.002

Keller, K.L. (1993). Conceptualizing, measuring, and managing customer-based brand equity. Journal of Marketing, 57(1), 1-22. doi: 10.1177/002224299305700101

Kempiak, J., Hollywood, L., Bolan, P., \& McMahon-Beattie, U. (2017). The heritage tourist: an understanding of the visitor experience at heritage attractions. International Journal of Heritage Studies, 23(4), 375-392. doi: 10.1080/13527258.2016.1277776

Kim, H., \& Jamal, T. (2007). Touristic quest for existential authenticity. Annals of Tourism Research, 34(1), 181-201. doi: 10.1016/j.annals.2006.07.009

Kozinets, R.V. \& Handelman, J. (1998). Ensouling consumption: a netnographic exploration of the meaning of boycotting behavior, in J.W. Alba and J.W. Hutchinson (Eds.), Advances in Consumer Research, 25, Provo, Utah, Association for Consumer Research, 475-480.

Kozinets, R.V. (2008). Technology/ideology: How ideological fields influence consumers' technology narratives. Journal of Consumer Research, 34(6), 865-881. doi: 10.1086/523289

Lee, M., Roux, D., Cherrier, H., \& Cova, B. (2011). Anti-consumption and consumer resistance: concepts, concerns, conflicts and convergence. European Journal of Marketing, 45(11/12). doi: 10.1108/ejm.2011.00745kaa.001

Leigh, T.W., Peters, C., \& Shelton, J. (2006). The consumer quest for authenticity: The multiplicity of meanings within the MG subculture of consumption. Journal of the Academy of Marketing Science, 34(4), 481-493. doi: 10.1177/0092070306288403

Logkizidou, M., Bottomley, P., Angell, R., \& Evanschitzky, H. (2018). Why Museological Merchandise Displays Enhance Luxury Product Evaluations: An Extended Art Infusion Effect, Journal of Retailing, 95(1), 67-82. doi.org/10.1016/j.jretai.2018.11.001 
Lowenthal, D. (1998). The Heritage Crusade and the Spoils of History. New York, NY: Cambridge University Press.

Mani, Z., \& Chouk, I. (2017). Drivers of consumers' resistance to smart products. Journal of Marketing Management, 33(1-2), 76-97. doi: 10.1080/0267257X.2016.1245212

Massara, F., \& Severino, F. (2013). Psychological distance in the heritage experience. Annals of Tourism Research, 42, 108-129. doi: 10.1016/j.annals.2013.01.005

McDonald, H. (2011). Understanding the antecedents to public interest and engagement with heritage. European Journal of Marketing, 45(5), 780-804. doi: 10.1108/03090561111120037

Melewar, T.C. (2003). Determinants of the corporate identity construct: a review of the literature. Journal of Marketing Communications, 9(4), 195-220. doi: 10.1080/1352726032000119161

Miles, M.B. (1979). Qualitative data as an attractive nuisance: The problem of analysis. Administrative Science Quarterly, 24(4), 590-601. doi: 10.2307/2392365

Minkiewicz, J., Evans, J., \& Bridson, K. (2014). How do consumers co-create their experiences? An exploration in the heritage sector. Journal of Marketing Management, 30(1-2), 30-59. doi: 10.1080/0267257x.2013.800899

Odou, P., \& De Pechpeyrou, P. (2011). Consumer cynicism: From resistance to anti-consumption in a disenchanted world? European Journal of Marketing, 45(11/12), 1799-1808. doi: 10.1108/03090561111167432

Otnes, C., \& Maclaren, P. (2007). The consumption of cultural heritage among a British Royal family brand tribe. In B. Cova, R. Kozinets \& A. Shankar (Eds.), Consumer tribes. Oxford, MA: Elsevier, 51-66.

Park, H.Y. (2010). Heritage tourism: Emotional journeys into nationhood. Annals of Tourism Research, 37(1), 116-135. doi: 10.1016/j.annals.2009.08.001

Pecot, F., \& De Barnier, V. (2017). Brand heritage: The past in the service of brand management. Recherche et Applications en Marketing (English Edition), 32(4), 72-90. doi: 10.1177/2051570717699376

Pecot, F., Merchant, A., Valette-Florence, P., \& De Barnier, V. (2018). Cognitive outcomes of brand heritage: A signaling perspective. Journal of Business Research, 85, 304-316. doi: 10.1016/j.jbusres.2018.01.016

Peñaloza, L., \& Price, L. (1993), Consumer resistance: a conceptual overview, in L. McAlister and M. Rothschild (Eds.), Advances in Consumer Research, 20, Provo, Utah, Association for Consumer Research, 123-128.

Poria, Y., Biran, A., \& Reichel, A. (2009). Visitors' preferences for interpretation at heritage sites. Journal of Travel Research, 48(1), 92-105. doi: 10.1177/0047287508328657 
Poria, Y., Butler, R., \& Airey, D. (2003). The core of heritage tourism. Annals of Tourism Research, 30(1), 238-254. doi: 10.1016/S0160-7383(02)00064-6

Prentice, R. (2001). Experiential cultural tourism: Museums and the marketing of the new romanticism of evoked authenticity. Museum Management and Curatorship, 19(1), 5-26. doi: 10.1016/s02604779(01)00002-4

Prentice, R., Guerin, S., \& McGugan, S. (1998). Visitor learning at a heritage attraction: a case study of Discovery as a media product. Tourism Management, 19(1), 5-23. doi: 10.1016/s02615177(97)00077-0

Riegl, A. (1982). The modern cult of monuments: its character and its origin. Oppositions, 25, 20-51.

Rindell, A., Santos, F.P., \& de Lima, A.P. (2015). Two sides of a coin: Connecting corporate brand heritage to consumers' corporate image heritage. Journal of Brand Management, 22(5), 467484.doi: $10.1057 / \mathrm{bm} .2015 .20$

Rodner, V.L., \& Kerrigan, F. (2014). The art of branding- lessons from visual artists. Arts Marketing: An International Journal, 4(1/2), 101-118. doi: /10.1108/AM-02-2014-0013

Rodner, V.L., \& Preece, C. (2015). Tainted museums: 'selling out' cultural institutions. International Journal of Nonprofit and Voluntary Sector Marketing. 20(2), 149-169. doi: 10.1002/nvsm.1527

Rose, G.M., Merchant, A., Orth, U.R., \& Horstmann, F. (2016). Emphasizing brand heritage: Does it work? And how? Journal of Business Research, 69(2), 936-943. doi: 10.1016/j.jbusres.2015.06.021

Roux, D. (2007). Consumer resistance: proposal for an integrative framework. Recherche et Applications en Marketing (English Edition), 22(4), 59-79. doi: 10.1177/205157070702200403

Roux, D. (2008), Consumers faced with telephone selling: Metacognition, resistance and strategies, Advances in Consumer Research, North American Conference Proceedings, 35, 1, eds. Angela Y. Lee et Dilip Soman, 467-474.

Santos, F.P., Burghausen, M., \& Balmer, J.M. (2016). Heritage branding orientation: The case of Ach. Brito and the dynamics between corporate and product heritage brands. Journal of Brand Management, 23(1), 67-88. doi: 10.1057/bm.2015.48

Smith, L. (2006). Uses of heritage. New York, USA: Routledge.

Sørensen, A.R., Korsager, E.M., \& Heller, M. (2018). A bittersweet past: The negative equity of corporate heritage brands. Journal of Consumer Culture, doi: 1469540518773803.

Spiggle, S. (1994). Analysis and interpretation of qualitative data in consumer research. Journal of Consumer Research, 21(3), 491-503. doi: 10.1086/209413

Stake, R. (1995). The art of case study research. London: Sage. 
Thompson, C.J. (1997). Interpreting consumers: a hermeneutical framework for deriving marketing insights from the texts of consumers' consumption stories. Journal of Marketing Research, 34, 438455. doi: /10.2307/3151963

Urde, M., Greyser, S.A., \& Balmer, J.M. (2007). Corporate brands with a heritage. Journal of Brand Management, 15(1), 4-19. doi: 10.1057/palgrave.bm.2550106

Vukadin, A., Lemoine, J.F., \& Badot, O. (2016). Opportunities and risks of combining shopping experience and artistic elements in the same store: a contribution to the magical functions of the point of sale. Journal of Marketing Management,32(9-10), 944-964. doi: 10.1080/0267257x.2016.1186106

Waitt, G. (2000). Consuming heritage: Perceived historical authenticity. Annals of Tourism Research. 27(4), 835-862. doi: 10.1016/S0160-7383(99)00115-2

Wallendorf, M., \& Brucks, M. (1993). Introspection in consumer research: implementation and implications. Journal of Consumer Research, 20(3), 339-359. doi: 10.1086/209354

Wiedmann, K.P., Hennigs, N., Schmidt, S., \& Wuestefeld, T. (2011). The importance of brand heritage as a key performance driver in marketing management. Journal of Brand Management, 19(3), 182194. doi: $10.1057 / \mathrm{bm} .2011 .36$

Woisetschläger, D.M., Haselhoff, V.J., \& Backhaus, C. (2014). Fans' resistance to naming right sponsorships: why stadium names remain the same for fans. European Journal of Marketing, 48(7/8), 1487-1510. doi: 10.1108/EJM-03-2012-0140

Xie, P.F. (2006). Developing industrial heritage tourism: A case study of the proposed jeep museum in Toledo, Ohio. Tourism Management, 27(6), 1321-1330. doi: 10.1016/j.tourman.2005.06.010!

Yin, R.K. (2013). Case study research: Design and methods. New York, USA: Sage publications. 
Appendix 1: narratives coding process
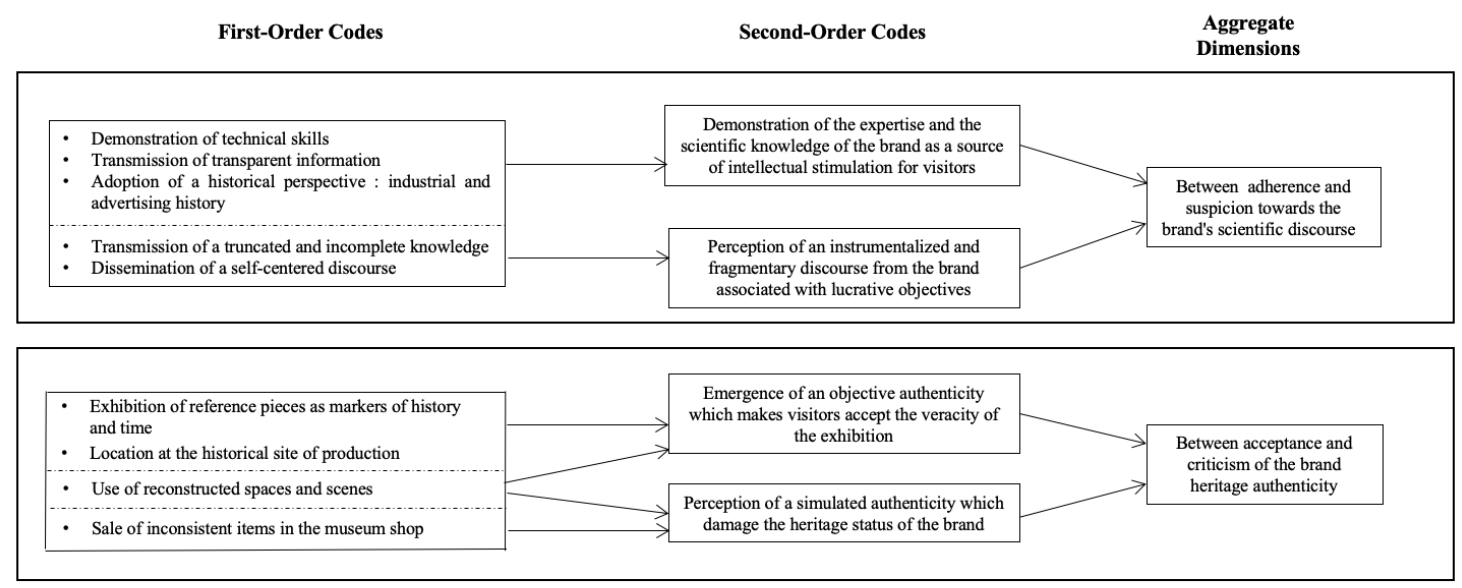

\begin{tabular}{|l|l|l|}
\hline - Aestheticization of industrial and technical objects & - Museum's architecture and exhibition scenography \\
\hline- Aestheticization of commercial and advertising materials
\end{tabular}

